\title{
Integration of MACBETH and COPRAS methods to select air compressor for a textile company
}

\author{
Nilsen Kundakcı* and Ayșegül Tuş Ișıık
}

Assistant Professor, Department of Business Administration, Pamukkale University, Denizli, Turkey

\begin{tabular}{l}
\hline C H R O N I C L E \\
\hline Article history: \\
Received October 25, 2015 \\
Received in revised format: \\
December 12, 2015 \\
Accepted February 14, 2016 \\
Available online \\
Februray 142016 \\
\hline Keywords: \\
Air compressor selection \\
MCDM \\
MACBETH method \\
COPRAS method \\
\end{tabular}

\section{A B S T R A C T}

\begin{abstract}
The selection of air compressor is a Multiple Criteria Decision Making (MCDM) problem including conflicting criteria and various alternatives. Selecting the appropriate air compressor is an important decision for the company as it affects the energy consumption and operating cost. To aid the decision making process in the companies, MCDM methods are proposed in the literature. In all MCDM methods, the main goal is to select the best alternative or to rank a set of given alternatives. In this paper, the air compressor is selected for a spinning mill of a textile company with an integrated approach based on MACBETH (Measuring Attractiveness by a Categorical Based Evaluation TecHnique) and COPRAS (COmplex PRoportional ASsessment) methods. MACBETH method is utilized to determine the weights of the criteria. Then COPRAS method is used to determine the ranking of the alternatives and select the best one.
\end{abstract}

(C) 2016 Growing Science Ltd. All rights reserved.

\section{Introduction}

Air compressors are widely used in industries to convert power using an electric motor, diesel or gasoline engine, etc. into potential energy stored in pressurized air. An air compressor forces more and more air into a storage tank by increasing the pressure. The energy contained in the compressed air can be used for a variety of applications. There are many types of air compressors, thus a proper selection is needed to fulfil the typical necessity of each company. Selection of an air compressor is a decision characterized by multiple criteria. In order to evaluate the overall efficiency of an air compressor it is necessary to identify selection criteria and to develop methods for evaluating the criteria and alternatives to meet the companies' needs. MCDM methods are proposed for the situations in which a decision maker has to choose among several alternatives by considering a common set of criteria. In the literature there are studies that apply different MCDM methods to the selection problems of textile companies. For instance, Ertuğrul and Karakaşoğlu (2008) selected a facility location for a textile

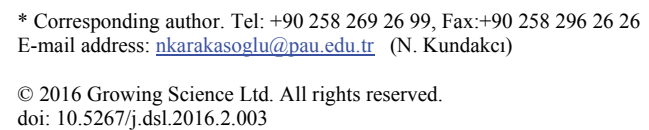


company with fuzzy AHP (Analytic Hierarch Process) and TOPSIS (Technique for Order Preference by Similarity to Ideal Solution) methods. Cebeci (2009) compared ERP (Enterprise Resource Planning) systems with fuzzy AHP for a textile company. Ilangkumaran and Kumanan (2009) proposed fuzzy AHP and TOPSIS for selecting the best maintenance strategy for a textile industry. Yayla et al. (2013) selected subcontractor for a textile company by using generalized Choquet integral methodology. Mokhtari et al. (2013) proposed fuzzy Delphi, fuzzy AHP and VIKOR (Vise Kriterijumska Optimizacija I Kompromisno Resenje) methods for supplier selection in textile industry. In this paper, different selection problem of a textile company is considered. Integrated approach based on MACBETH and COPRAS methods are proposed for the air compressor selection of a textile company. MACBETH method is used to determine the weights of the criteria. Then the ranking of the alternatives are determined with COPRAS method. The main contribution of this paper to the literature is to integrate MACBETH and COPRAS methods for the first time.

This paper is organized as follows: In the second section, the integrated method is introduced and also MACBETH and COPRAS methods are explained respectively. In the third section, application of the integrated method in a spinning mill of a textile company is given. Finally, result of the integrated method are discussed and suggestions for future research are offered in the last section.

\section{Integrated Method}

In this section, MACBETH and COPRAS methods are integrated for selecting the best air compressor alternative for the spinning mill of a textile company. MACBETH method is used for determining the weights of the criteria and then with COPRAS method the ranking of the alternatives are determined. So, in this section firstly MACBETH method is introduced and then COPRAS method is explained. Flow chart of the integrated method can be seen in Fig. 1.

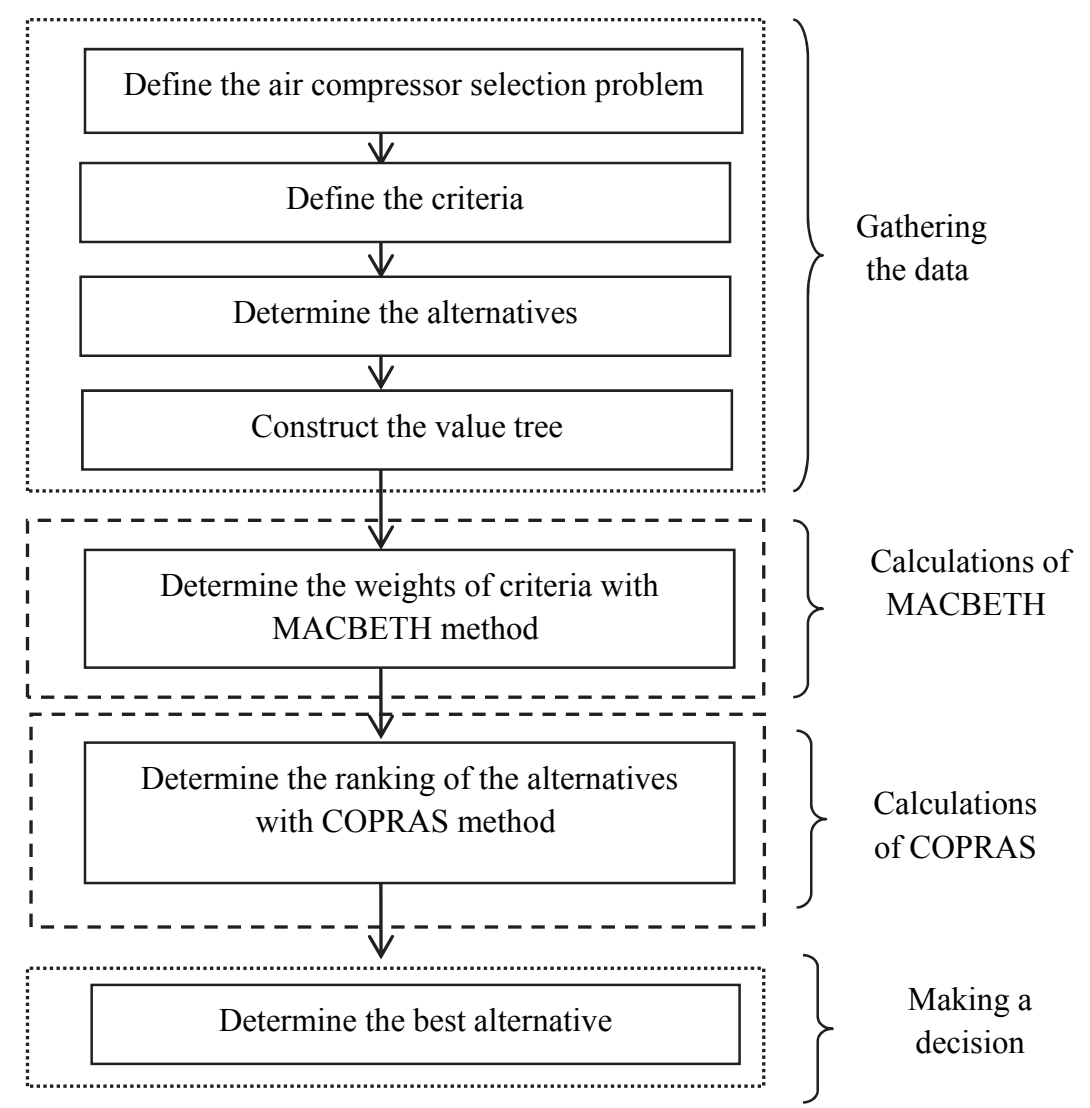

Fig. 1. Flow chart of the integrated method 


\subsection{MACBETH Method}

MACBETH (Measuring Attractiveness by a Categorical Based Evaluation TecHnique) is a MCDM method used to establish a quantitative model of values. It avoids decision makers to produce direct numerical representations of their preferences (Bana e Costa \& Chagas, 2004) and helps for determining the ranking of the alternatives based on aggregated value of relative weighted attractiveness of alternatives with respect to decision criteria (Karande \& Chakraborty, 2014).

MACBETH was firstly proposed by Bana e Costa, Vansnick and De Corte in 1990s. After introduced in the $\mathrm{XI}^{\text {th }}$ International Conference on MCDM, this method was applied to various fields (Burgazoğlu, 2015). For instance, Bana e Costa et al. (1999) solved complex strategic problems of Santa Catarina textile industry by integrating several decision support systems. Bana e Costa et al. (2001) integrated MACBETH and disaggregation-aggregation approaches for conflict dissolution in the construction of a new railway link to the port of Lisbon. Bana e Costa (2001) used MACBETH method for analyzing spatial conflicts in the investment policy of new inter-municipal road-links. Bana e Costa \& Oliveira (2002) determined the maintenance, repair and refurbishment priorities in managing a municipal housing stock. Bana e Costa et al. (2002a) used this method for the strategic town planning of Barcelos which was one of the medium sized Porteguese towns. Bana e Costa et al. (2002b) helped credit granting decisions in banking sector. Bana e Costa et al. (2002c) facilitated bid evaluation processes in public call for tenders. Bana e Costa \& Chagas (2004) used MACBETH method and software to solve career choice problem. Roubens et al. (2006) determined stable governments by developing a model for coalition formation with MACBETH method. Cliville et al. (2007) used MACBETH method to determine the industrial performance expressions. Montignac et al. (2009) compared the technical performance of hydrogen storage technologies with MACBETH method. Fakhfakh et al. (2011) combined MACBETH method with workflow patterns aggregation rules for measuring the satisfaction degree of services orchestration. Karandea \& Chakraborty (2013) used MACBETH method to solve supplier selection problems. Rodrigues (2014) proposed MACBETH method to build a multidimensional value-based population health indices. Karande and Chakraborty (2014) solved facility layout selection problems with MACBETH method. Lastly, Dhouib (2014) applied fuzzy MACBETH method to evaluate reverse logistics alternatives for the automobile tire wastes.

Steps of the MACBETH method can be summarized as follows:

Step 1. Decision criteria are defined and expressed in the form of a value tree.

Step 2. Then alternatives and the ordinal performance levels of them with respect to each criterion are defined. Minimum two reference levels are required to be identified as upper reference (good) level and lower reference (neutral) level. The upper reference level denotes the score of 100 while lower reference level denotes the score of 0 on MACBETH scale. But 100 does not always show the best performance and also 0 does not indicate the worst performance of an alternative (Karande \& Chakraborty, 2013).

Step 3. The alternatives are arranged in an $m \times m$ matrix form from left to right according to their importance to quantify the qualitative performance levels or convert quantitative performance levels into proportionate MACBETH scale. Here $m$ indicates the number of alternatives selected for that criterion. Also the same procedure is applied for the criteria.

Step 4. Pairwise comparisons are made for the criteria and alternatives based on difference of attractiveness. MACBETH method uses a semantic scale set with seven categories to indicate the difference of attractiveness. The equivalent numerical scales and significances of these semantic scales can be seen in Table 1 (Karande \& Chakraborty, 2013; Bana e Costa \&Chagas, 2004). 


\section{Table 1}

Semantic scale of MACBETH

\begin{tabular}{lll}
\hline $\begin{array}{l}\text { Semantic } \\
\text { Scale }\end{array}$ & $\begin{array}{l}\text { Equivalent } \\
\text { Numerical Scale }\end{array}$ & Significance \\
\hline Null & 0 & Indifference between alternatives \\
Very Weak & 1 & An alternative is very weakly attractive over another \\
Weak & 2 & An alternative is weakly attractive over another \\
Moderate & 3 & An alternative is moderately attractive over another \\
Strong & 4 & An alternative is strongly attractive over another \\
Very Strong & 5 & An alternative is very strongly attractive over another \\
Extreme & 6 & An alternative is extremely attractive over another \\
\hline
\end{tabular}

Step 5. The consistency of the decision makers' judgments are checked. If the judgments are inconsistent, M-MACBETH software recommends possible changes to make the judgments consistent (Bana e Costa \& Oliveira, 2002).

Step 6. The consistent judgments are transformed into a suitable numerical scale, identified as the MACBETH scale based on linear programming models.

Step 7. Finally, the weighted global scores representing the overall attractiveness of the considered alternatives are computed using an additive aggregation model to rank the alternatives.

In order to obtain quantified MACBETH scores of qualitative performance levels, the following procedure is adopted (Karande \& Chakraborty, 2013; 2014; Fakhfakh et al., 2011).

Firstly, decision maker is asked about his/her preferences between pairs of alternatives under each criterion. If the decision maker prefers alternative $A_{i}$ to $A_{i^{\prime}}$ for a criterion $j$, this is noted as follows:

$$
A_{i}>A_{i^{\prime}}
$$

Secondly, the decision maker expresses his/her strengths of preference about the alternatives. The strengths of preference are characterized with semantic scale in Table 1. If the decision maker cannot give his/her strengths of preference but only his/her preferences, this is noted by positive or more shortly $P$. The decision maker prefers the alternative $A_{i}$ to $A_{i^{\prime}}$ with strength $h \in\{0,1,2,3,4,5,6\}$ for a criterion $j$,

$$
A_{i} \succ^{h} A_{i^{\prime}}
$$

This is equivalent to:

$$
A_{i}-A_{i^{\prime}}=h \alpha
$$

Here $\alpha$ is a coefficient necessary to meet condition $A_{i}$ and $A_{i^{\prime}} \in[0,100]$. Consider an example with four alternatives and their preference for importance for the $j^{\text {th }}$ criterion are as $A_{4}>A_{1}>A_{3}>A_{2}$. If $v_{j}\left(A_{4}\right), v_{j}\left(A_{1}\right), v_{j}\left(A_{3}\right)$ and $v_{j}\left(A_{2}\right)$ are MACBETH scores for $A_{4}, A_{1}, A_{3}, A_{2}$ respectively, then $v_{j}\left(A_{4}\right)=100$, $v_{j}\left(A_{2}\right)=0$ and $v_{j}\left(A_{4}\right)>v_{j}\left(A_{1}\right)>v_{j}\left(A_{3}\right)>v_{j}\left(A_{2}\right)$. Then, decision maker expresses his/her strengths of preferences for alternatives using seven semantic scale in Table 1. These preference strengths of alternatives for $j^{\text {th }}$ criterion are given in Table 2 .

Table 2

Preference strengths of alternatives for $j^{\text {th }}$ criterion

\begin{tabular}{lllll}
\hline Alternatives & $A_{4}$ & $A_{1}$ & $A_{3}$ & $A_{2}$ \\
\hline$A_{4}$ (good) & No & Very Strong & $\mathrm{P}$ & $\mathrm{P}$ \\
$A_{1}$ & & No & Strong & $\mathrm{P}$ \\
$A_{3}$ & & No & Very Weak \\
$A_{2}$ (neutral) & & & & No \\
\hline
\end{tabular}


From the data provided from Table 2, these equation systems can be extracted;

$$
\begin{aligned}
& v_{j}\left(A_{4}\right)-v_{j}\left(A_{1}\right)=5 \alpha \\
& v_{j}\left(A_{1}\right)-v_{j}\left(A_{3}\right)=4 \alpha \\
& v_{j}\left(A_{3}\right)-v_{j}\left(A_{2}\right)=\alpha
\end{aligned}
$$

As mentioned before, $v_{j}\left(A_{4}\right)=100(\mathrm{good})$ and $v_{j}\left(A_{2}\right)=0$ (neutral). By solving equations (4) - (6) the obtained solutions are $\alpha=10, v_{j}\left(A_{1}\right)=50$ and $v_{j}\left(A_{3}\right)=10$.

The quantification of alternatives for all the remaining criteria as well as the corresponding criteria weights can be obtained adopting the same procedure. Then the MACBETH scores are multiplied with the criteria weights and added for finding the overall scores of alternatives. The final overall score is obtained using the following additive value model (Karande \& Chakraborty, 2014; Bana e Costa el al., 2002b):

$$
\begin{aligned}
& V\left(A_{i}\right)=\sum_{j=1}^{n} w_{j}\left(v_{j}\left(A_{i}\right)\right) \\
& \sum_{j=1}^{n} w_{j}=1, \quad w_{j}>0 \quad \text { and }\left\{\begin{array}{l}
v_{j}\left(A_{i}^{\text {good }}\right)=100 \\
v_{j}\left(A_{i}^{\text {neutral }}\right)=0
\end{array}\right.
\end{aligned}
$$

Here $w_{j}$ indicates weight of the $j^{\text {th }}$ criterion. The final ranking of the alternatives is determined based on the $V\left(A_{i}\right)$ values. This method is also supported by M-MACBETH software (http://www.mmacbeth.com/en/downloads.html) developed using algorithm based on linear programming models (Karande and Chakraborty, 2013). In this paper, M-MACBETH software is used while determining the weights of the criteria.

\subsection{COPRAS Method}

The COPRAS (COmplex PRoportional ASsessment) method was first introduced by Zavadskas, Kaklauskas and Sarka in 1994. This method compares the alternatives and determines their priorities under the conflicting criteria by taking into account the criteria weights (Zavadskas et al., 2009). It assumes direct and proportional dependences of the significance and utility degree (priority) of the alternatives. This method selects the best alternative considering both the ideal and the ideal-worst solutions (Chatterjee \& Chakraborty, 2014).

COPRAS method due to its simplicity was applied to the various problems in different fields like construction, property management, economics etc. Zavadskas et al. (2001) proposed COPRAS method for assessing building life cycles to select the best alternative. Vilutienè and Zavadskas (2003) determined the effective variant of a dwelling maintenance work and performance with this method. Zavadskas et al. (2004) used COPRAS method for developing a housing credit access model. Zavadskas and Vilutiene (2004) determined the appropriate maintenance contractors for apartment blocks. Kaklauskas et al. (2005) proposed COPRAS method for designing and refurbishment of building. Andruškevicius (2005) used this method for selecting the best contractor for the construction of a trade and entertainment center. Kaklauskas et al. (2006) evaluated contractors for the replacement of windows in Vilnius Gediminas Technical University main building. Kaklauskas et al. (2007a) selected the best construction alternative with COPRAS method. Kaklauskas et al. (2007b) determined the market value of real estate with help of COPRAS method. Zavadskas et al. (2007) proposed to use COPRAS method for evaluating road design alternatives. Viteikienė and Zavadskas (2007) used COPRAS method for evaluating the sustainability of residential areas in Vilnius City. Zagorskas et al. 
(2007) determined sustainable city compactness by using COPRAS method. Banaitiene et al. (2008) used COPRAS method to select a building's life cycle. Kaklauskas et al. (2010) evaluated intelligent built environment alternatives in industrialized countries. Kanapeckiene et al. (2010) proposed Knowledge Based Decision Support System for Construction Projects Management (KDSS-CPM) to select a land parcel from the alternatives. Das et al. (2012) applied COPRAS method to measure relative performance of Indian technical institutions. Mulliner et al. (2013) evaluated the affordability of different housing locations by considering economic, environmental and social criteria. Chatterjee and Chakraborty (2014) used COPRAS method to select the most appropriate Flexible Manufacturing System (FMS) for a manufacturing firm. Also, COPRAS-G method was used for the selection of investment project (Popovic et al., 2012), the effective dwelling house walls (Zavadskas et al., 2008a), construction project manager (Zavadskas et al., 2008b), contractor (Zavadskas et al., 2008c), best web site (Bindu Madhuri et al., 2010) and material (Chatterjee \& Chakraborty (2012); Maity et al. (2012))

The procedure of the COPRAS method consists of the steps as below (Chatterjee \& Chakraborty, 2014):

Step 1: The decision matrix is normalized with linear normalization procedure using the following formula (Kaklauskas et al., 2006):

$$
x_{i j}^{*}=\frac{x_{i j}}{\sum_{i=1}^{m} x_{i j}}(i=1,2, \ldots, m ; j=1,2, \ldots, n)
$$

where $x_{i j}$ is the performance of the $i^{\text {th }}$ alternative with respect to the $j^{\text {th }}$ criterion, $x_{i j}^{*}$ is its normalized value, and $m$ is number of alternatives. When performing multiple criteria evaluation of the alternatives, the values of the criteria describing them should be normalized. This provides a possibility to compare the values of the criteria having different units of measurement (Zavadskas et al., 2009).

Step 2: Weighted normalized decision making matrix $(D)$ is formed as,

$$
D=\left[d_{i j}\right]_{m x n}=x_{i j}^{*} \cdot w_{j}
$$

where $w_{j}$ represents the importance weight of criterion $C_{j}$.

Step 3: The sums of weighted normalized values are calculated for both beneficial and nonbeneficial criteria as:

$$
\begin{aligned}
& S_{+i}=\sum_{j=1}^{n} d_{+i j} \\
& S_{-i}=\sum_{j=1}^{n} d_{-i j}
\end{aligned}
$$

where $d_{+i j}$ and $d_{-i j}$ are the weighted normalized values for the beneficial and non-beneficial criteria respectively. The greater the value of $S_{+i}$, the better is the alternative; and the lower the value of $S_{-i}$, the better is the alternative. The $S_{+i}$ and $S_{-i}$ values express the degree of goals attained by each alternative. In any case, the sums of $S_{+i}$ and the sums of $S_{-i}$ are equal to the weighted sums for the beneficial and non-beneficial criteria as expressed by the following equations:

$$
\begin{aligned}
& \sum_{i=1}^{m} S_{+i}=\sum_{i=1}^{m} \sum_{j=1}^{n} d_{+i j} \\
& \sum_{i=1}^{m} S_{-i}=\sum_{i=1}^{m} \sum_{j=1}^{n} d_{-i j}
\end{aligned}
$$


Step 4: The relative significances or priorities $\left(Q_{i}\right)$ of each alternative are determined using the following formula:

$$
Q_{i}=S_{+i}+\frac{S_{-\min } \sum_{i=1}^{m} S_{-i}}{S_{-i} \sum_{i=1}^{m}\left(S_{-\min } / S_{-i}\right)}=S_{+i}+\frac{\sum_{i=1}^{m} S_{-i}}{S_{-i} \sum_{i=1}^{m}\left(1 / S_{-i}\right)} \quad(i=1,2, \ldots, m)
$$

where $S_{\text {-min }}$ is the minimum value of $S_{-i}$. The greater the value of $Q_{i}$, the higher is the priority of the alternative. The relative significance value of an alternative shows the degree of satisfaction attained by that alternative. The alternative with the highest relative significance value $\left(Q_{\max }\right)$ is the best choice among the alternatives.

Step 5: The quantitative utility $\left(U_{i}\right)$ for each alternative is calculated. The degree of an alternative's utility which leads to a complete ranking of the alternatives, is determined by comparing the priorities of all the alternatives with the most efficient one and can be denoted as below:

$$
U_{i}=\left[\frac{Q_{i}}{Q_{\max }}\right] x 100 \%
$$

where $Q_{\max }$ is the maximum relative significance value. These utility values of the alternatives range from $0 \%$ to $100 \%$.

\section{Application}

The main objective of this paper is to select the best air compressor for a spinning mill of a textile company. This textile company established in Denizli and it is a fully integrated facility which performs production of spinning, weaving, knitting, dying and confection. Their major product range includes all kinds of towels \& bathrobes, kitchen home textile products, home wear and beach wear products. The textile company decides to buy an air compressor for using in its spinning mill. They need screw air compressor driven by inverter motor. This kind of air compressor which is to be used in spinning mill that has variable air requirements, provides energy saving and improves the air compressor's service life. There are many air compressor alternatives in the market and conflicting criteria to be considered, so the air compressor selection is a crucial and difficult decision for the company. For selecting the best air compressor for this textile company an integrated method based on MACBETH and COPRAS methods are proposed. The weights of the decision criteria are determined with MACBETH method and then the ranking of the alternatives is determined by COPRAS method.

First of all, decision criteria are defined and expressed in the form of a value tree as seen in Figure 2. These criteria are; $\mathrm{C}_{1}$ Energy consumption ( $\mathrm{kw} /$ hour per day), $\mathrm{C}_{2}$ Maintenance cost (Euro per year), $\mathrm{C}_{3}$ Price (Euro), $\mathrm{C}_{4}$ Physical life of the compressor (year), $\mathrm{C}_{5}$ Maximum flow rate $\left(\mathrm{m}^{3} / \mathrm{min}^{3}, \mathrm{C}_{6}\right.$ Minimum flow rate $\left(\mathrm{m}^{3} / \mathrm{min}\right), \mathrm{C}_{7}$ Brand reliability, $\mathrm{C}_{8}$ Service quality and $\mathrm{C}_{9}$ Scrap value of the compressor (Euro).

In order to determine the weights of the criteria with MACBETH method, criteria are entered into MMACBETH software in descending order of their importance from left to right and top to bottom in the weighting matrix, as shown in Table 3. 


\section{Compressor Selection}

$\mathrm{C}_{1}$ Energy consumption

$\mathrm{C}_{2}$ Maintenance cost

$\mathrm{C}_{3}$ Price

$\mathrm{C}_{4}$ Physical life of the compressor

$\mathrm{C}_{5}$ Maximum flow rate

$\mathrm{C}_{6}$ Minimum flow rate

$\mathrm{C}_{7}$ Brand reliability

$\mathrm{C}_{8}$ Service quality

$\mathrm{C}_{9}$ Scrap value of the compressor

Figure 2. MACBETH value tree for air compressor selection problem

Table 3

Comparison of the criteria

\begin{tabular}{|c|c|c|c|c|c|c|c|c|c|c|}
\hline Criteria & $\mathrm{C}_{1}$ & $\mathbf{C}_{2}$ & $\mathrm{C}_{3}$ & $\mathrm{C}_{4}$ & $\mathrm{C}_{5}$ & $\mathrm{C}_{6}$ & $\mathbf{C}_{7}$ & $\mathrm{C}_{8}$ & $\mathrm{C}_{9}$ & $\begin{array}{l}\text { Current } \\
\text { Scale }\end{array}$ \\
\hline$C_{1}$ & no & $\begin{array}{l}\text { very } \\
\text { weak }\end{array}$ & weak & moderate & strong & strong & v.strong & extreme & extreme & 20.27 \\
\hline $\mathrm{C}_{2}$ & & no & $\begin{array}{l}\text { very } \\
\text { weak }\end{array}$ & weak & moderate & moderate & strong & v.strong & extreme & 17.57 \\
\hline $\mathrm{C}_{3}$ & & & no & $\begin{array}{l}\text { very } \\
\text { weak }\end{array}$ & weak & moderate & strong & v.strong & extreme & 16.22 \\
\hline $\mathrm{C}_{4}$ & & & & no & $\begin{array}{l}\text { very } \\
\text { weak }\end{array}$ & weak & moderate & strong & v.strong & 13.51 \\
\hline $\mathrm{C}_{5}$ & & & & & no & $\begin{array}{l}\text { very } \\
\text { weak }\end{array}$ & weak & moderate & strong & 10.81 \\
\hline $\mathrm{C}_{6}$ & & & & & & no & $\begin{array}{l}\text { very } \\
\text { weak }\end{array}$ & weak & moderate & 9.46 \\
\hline $\mathrm{C}_{7}$ & & & & & & & no & $\begin{array}{l}\text { very } \\
\text { weak }\end{array}$ & weak & 6.76 \\
\hline $\mathrm{C}_{8}$ & & & & & & & & no & $\begin{array}{l}\text { very } \\
\text { weak }\end{array}$ & 4.05 \\
\hline $\mathrm{C}_{9}$ & & & & & & & & & no & 1.35 \\
\hline
\end{tabular}

In order to convert the performance levels for all criteria into proportionate quantitative MACBETH scores, they are pair-wise compared with the help of a seven point semantic scale. M-MACBETH software checked the consistency of these judgments and it is found that the entered judgments are 
entirely consistent. Further, based on the provided differences of attractiveness, M-MACBETH software converts the ordinal performance levels into proportionate cardinal MACBETH scale using appropriate linear programming models. This MACBETH scale can be seen in the last column of the Table 3 and these values show the weights of the criteria. The weights of the criteria obtained with the MACBETH method can be summarized as in Table 4.

Table 4

Weights of the criteria

\begin{tabular}{llllllllll}
\hline Criteria & $\mathrm{C}_{1}$ & $\mathrm{C}_{2}$ & $\mathrm{C}_{3}$ & $\mathrm{C}_{4}$ & $\mathrm{C}_{5}$ & $\mathrm{C}_{6}$ & $\mathrm{C}_{7}$ & $\mathrm{C}_{8}$ & $\mathrm{C}_{9}$ \\
\hline Weights & 0.2027 & 0.1757 & 0.1622 & 0.1351 & 0.1081 & 0.0946 & 0.0676 & 0.0405 & 0.0135 \\
\hline
\end{tabular}

After determining the weights of the criteria with MACBETH method, COPRAS method is used to determine the ranking of the air compressor alternatives. After a preliminary research, mechanical engineer of the textile company determined six possible air compressor alternatives. In COPRAS method firstly decision matrix is formed as seen in Table 5. In this table, quantitative data for performance evaluation of alternatives are summarized. The data for $\mathrm{C}_{1}, \mathrm{C}_{2}, \mathrm{C}_{3}, \mathrm{C}_{4}, \mathrm{C}_{5}, \mathrm{C}_{6}$ and $\mathrm{C}_{9}$ are quantitative data whereas data for the $\mathrm{C}_{7}$ and $\mathrm{C}_{8}$ are qualitative data and while obtaining these values decision maker evaluated the alternatives by using 5 point scale $(5=$ Excellent, $4=$ Very good, $3=$ Good, 2=Fair, 1=Poor). Compressor selection criteria can be categorized as beneficial and non-beneficial. Among these nine criteria $\mathrm{C}_{4}, \mathrm{C}_{5}, \mathrm{C}_{7}, \mathrm{C}_{8}$ and $\mathrm{C}_{9}$ are beneficial where higher values are desirable; $\mathrm{C}_{1}$, $\mathrm{C}_{2}, \mathrm{C}_{3}$ and $\mathrm{C}_{6}$ are non-beneficial where smaller value is always preferred. Beneficial criteria are maximized whereas non-beneficial criteria are minimized.

Table 5

Quantitative data for performance evaluation of alternatives

\begin{tabular}{llllllllll}
\hline Optimization direction & $\min$ & $\min$ & $\min$ & $\max$ & $\max$ & $\min$ & $\max$ & $\max$ & $\max$ \\
\hline Alternatives & $\mathrm{C}_{1}$ & $\mathrm{C}_{2}$ & $\mathrm{C}_{3}$ & $\mathrm{C}_{4}$ & $\mathrm{C}_{5}$ & $\mathrm{C}_{6}$ & $\mathrm{C}_{7}$ & $\mathrm{C}_{8}$ & $\mathrm{C}_{9}$ \\
\hline $\mathrm{A}_{1}$ & 1543 & 2000 & 39000 & 15 & 13.76 & 3.86 & 5 & 3 & 5000 \\
$\mathrm{~A}_{2}$ & 1496 & 3600 & 43000 & 14 & 14 & 2.5 & 4 & 4 & 4000 \\
$\mathrm{~A}_{3}$ & 1584 & 3100 & 24500 & 10 & 13.1 & 3.7 & 2 & 2 & 3500 \\
$\mathrm{~A}_{4}$ & 1560 & 2700 & 36000 & 12 & 13.2 & 3.2 & 3 & 3 & 3500 \\
$\mathrm{~A}_{5}$ & 1572 & 2500 & 31500 & 13 & 13.3 & 3.4 & 3 & 2 & 3500 \\
$\mathrm{~A}_{6}$ & 1580 & 2400 & 20000 & 12 & 12.8 & 3.9 & 2 & 2 & 3000 \\
\hline Total & 9335 & 16300 & 194000 & 76 & 80.16 & 20.56 & 19 & 16 & 22500 \\
\hline
\end{tabular}

After forming the decision matrix, this matrix is normalized by using Eq. (9) as shown in Table 6.

Table 6

Normalized decision matrix

\begin{tabular}{|c|c|c|c|c|c|c|c|c|c|}
\hline Alternatives & $\mathrm{C}_{1}$ & $\mathrm{C}_{2}$ & $\mathrm{C}_{3}$ & $\mathrm{C}_{4}$ & $\mathrm{C}_{5}$ & $\mathrm{C}_{6}$ & $\mathrm{C}_{7}$ & $\mathrm{C}_{8}$ & $\mathrm{C}_{9}$ \\
\hline $\mathrm{A}_{1}$ & 0.1653 & 0.1227 & 0.2010 & 0.1974 & 0.1717 & 0.1877 & 0.2632 & 0.1875 & 0.2222 \\
\hline $\mathrm{A}_{2}$ & 0.1603 & 0.2209 & 0.2216 & 0.1842 & 0.1747 & 0.1216 & 0.2105 & 0.2500 & 0.1778 \\
\hline $\mathrm{A}_{3}$ & 0.1697 & 0.1902 & 0.1263 & 0.1316 & 0.1634 & 0.1800 & 0.1053 & 0.1250 & 0.1556 \\
\hline $\mathrm{A}_{4}$ & 0.1671 & 0.1656 & 0.1856 & 0.1579 & 0.1647 & 0.1556 & 0.1579 & 0.1875 & 0.1556 \\
\hline $\mathrm{A}_{5}$ & 0.1684 & 0.1534 & 0.1624 & 0.1711 & 0.1659 & 0.1654 & 0.1579 & 0.1250 & 0.1556 \\
\hline $\mathrm{A}_{6}$ & 0.1693 & 0.1472 & 0.1031 & 0.1579 & 0.1597 & 0.1897 & 0.1053 & 0.1250 & 0.1333 \\
\hline
\end{tabular}

Then, the corresponding weighted normalized decision matrix is developed by using Eq. (10) as shown in Table 7. 
Table 7

Weighted normalized decision matrix

\begin{tabular}{llllllllll}
\hline Alternatives & $\mathrm{C}_{1}$ & $\mathrm{C}_{2}$ & $\mathrm{C}_{3}$ & $\mathrm{C}_{4}$ & $\mathrm{C}_{5}$ & $\mathrm{C}_{6}$ & $\mathrm{C}_{7}$ & $\mathrm{C}_{8}$ & $\mathrm{C}_{9}$ \\
\hline $\mathrm{A}_{1}$ & 0.0335 & 0.0216 & 0.0326 & 0.0267 & 0.0186 & 0.0178 & 0.0178 & 0.0076 & 0.0030 \\
$\mathrm{~A}_{2}$ & 0.0325 & 0.0388 & 0.0360 & 0.0249 & 0.0189 & 0.0115 & 0.0142 & 0.0101 & 0.0024 \\
$\mathrm{~A}_{3}$ & 0.0344 & 0.0334 & 0.0205 & 0.0178 & 0.0177 & 0.0170 & 0.0071 & 0.0051 & 0.0021 \\
$\mathrm{~A}_{4}$ & 0.0339 & 0.0291 & 0.0301 & 0.0213 & 0.0178 & 0.0147 & 0.0107 & 0.0076 & 0.0021 \\
$\mathrm{~A}_{5}$ & 0.0341 & 0.0269 & 0.0263 & 0.0231 & 0.0179 & 0.0156 & 0.0107 & 0.0051 & 0.0021 \\
$\mathrm{~A}_{6}$ & 0.0343 & 0.0259 & 0.0167 & 0.0213 & 0.0173 & 0.0179 & 0.0071 & 0.0051 & 0.0018 \\
\hline
\end{tabular}

The sums of the weighted normalized values for the beneficial criteria $\left(S_{+i}\right)$ and for the non-beneficial criteria $\left(S_{-i}\right)$ are calculated based on Eq. (11) and Eq. (12) as shown in Table 8.

Table 8

$\underline{S_{+i} \text { and } S_{-i} \text { values }}$

\begin{tabular}{lll}
\hline Alternatives & $S_{+i}$ & $S_{-i}$ \\
\hline $\mathrm{A}_{1}$ & 0.0736 & 0.1054 \\
$\mathrm{~A}_{2}$ & 0.0705 & 0.1187 \\
$\mathrm{~A}_{3}$ & 0.0497 & 0.1053 \\
$\mathrm{~A}_{4}$ & 0.0595 & 0.1078 \\
$\mathrm{~A}_{5}$ & 0.0589 & 0.1031 \\
$\mathrm{~A}_{6}$ & 0.0526 & 0.0948 \\
\hline
\end{tabular}

Then the relative significance or priority value $\left(Q_{i}\right)$ and the quantitative utility $\left(U_{i}\right)$ for each alternative are computed by applying Eq. (15) and Eq. (16) as shown in Table 9.

Table 9

$Q i$ and $U i$ values

\begin{tabular}{llll}
\hline Alternatives & $Q_{i}$ & $U_{i}$ & Rank \\
\hline $\mathrm{A}_{1}$ & 0.1794 & 100,0000 & 1 \\
$\mathrm{~A}_{2}$ & 0.1645 & 91,6705 & 4 \\
$\mathrm{~A}_{3}$ & 0.1557 & 86,7531 & 6 \\
$\mathrm{~A}_{4}$ & 0.1630 & 90,8437 & 5 \\
$\mathrm{~A}_{5}$ & 0.1672 & 93,1505 & 3 \\
$\mathrm{~A}_{6}$ & 0.1702 & 94,8626 & 2 \\
\hline
\end{tabular}

According to the calculation results, the complete ranking of the alternatives is obtained as $A_{1}>A_{6}>A_{5}>A_{2}>A_{4}>A_{3} . A_{1}$ is the best alternative with $100 \%$ utility degree.

\section{Conclusion}

In this paper, an integrated approach based on MACBETH and COPRAS methods is proposed for the first time and its applicability is illustrated with a real life problem of a textile company. Air compressor selection problem is considered where the decision criteria are energy consumption, maintenance cost, price, physical life of the compressor, maximum flow rate, minimum flow rate, brand reliability, service quality and scrap value of the compressor. These criteria are evaluated to determine the ranking of the air compressor alternatives to select the most appropriate for the spinning mill of the textile company. MACBETH method is utilized for determining the criteria weights and then ranking of the alternatives are determined with COPRAS method. The ranking of the six alternatives has been determined as $A_{1}>A_{6}>A_{5}>A_{2}>A_{4}>A_{3}$. According to the results, it is advised to the textile company to choose the $A_{1}$ 
air compressor for its spinning mill. The company management found the results satisfactory and decided to buy $A_{1}$ air compressor. Consequently, in this paper a scientific and integrated approach is proposed to the company that determines the best alternative intuitively by the help of experiences before.

The proposed integrated approach consists of two MCDM methods; MACBETH and COPRAS. These methods are chosen because they have some advantages over other MCDM methods. The weights of the criteria are determined with a relatively new method MACBETH. Also these weights can be determined with Analytic Hierarch Process (AHP). Although there are similarities between these two methods, there are differences in the manner within the phases must be conducted. In the phase of evaluation, there are also pairwise judgment as in the AHP with the use of a decision matrix. The main differences are in the scale to be used in the judgments and in the validation of these judgments. In the MACBETH the validation of judgments may also be obtained by the theoretical consistency checking and by the semantic consistency checking (Salomon \& Montevechi, 2001).

MACBETH has advantage over other MCDM methods is that only requires qualitative judgements to score alternatives and to weight the criteria. Furthermore, the MACBETH provides a visual preliminary consistency checking: in the judgment matrixes the attractiveness difference must increase from left to right and from bottom to up, given a necessary judgment sorting (Salomon \& Montevechi, 2001). On the other hand, the support of M-MACBETH software also improves the usefulness of this method in solving complex decision-making problems having performance of the alternatives expressed in ordinal scale (Karande \& Chakraborty, 2013).

COPRAS method has the potential to be popular, widely acceptable because it does not contain complex calculations and easy to apply to real life problems. Also COPRAS method is very useful when the number of alternatives and criteria are very high, because it does not need pair-wise comparison like PROMETHEE or ELECTRE methods. This method can provide a complete ranking of alternatives and deal with both quantitative and qualitative criteria within one assesment. It has the ability to account for both positive and negative evaluation criteria, which can be assessed separately within the evaluation process. An important feature that makes the COPRAS method superior to other available MCDM methods is that it may be used to estimate the utility degree of alternatives, showing, as a percentage, the extent to which one alternative is better or worse than other alternatives taken for comparison (Mulliner et al., 2013)

In future studies, proposed approach can also be applied to other MCDM problems of the company. In air compressor selection problem, AHP can be used to determine the weights of the criteria and other MCDM methods like TOPSIS, ELECTRE, PROMETHEE, VIKOR and MOORA can be used to determine the ranking of the alternatives and also the obtained results can be compared.

\section{References}

Andruškevicius, A. (2005). Evaluation of contractors by using COPRAS - the multiple criteria method. Technological and Economic Development of Economy, 11(3), 158-169.

Banaitiene, N., Banaitis, A., Kaklauskas, A., \& Zavadskas, E. K. (2008). Evaluating the life cycle of a building: A multivariant and multiple criteria approach. Omega, 36(3), 429-441.

Burgazoğlu, H, (2015). MACBETH, B.F. Yıldırım, E. Önder (Ed.), Çok Kriterli Karar Verme Yöntemleri, Bursa: Dora Yayınları.

Bana e Costa, C. A., Ensslin, L., Cornêa, É. C., \& Vansnick, J. C. (1999). Decision support systems in action: integrated application in a multicriteria decision aid process. European Journal of Operational Research, 113(2), 315-335.

Bana e Costa, C. A., \& Carlos, A. (2001). The use of multi-criteria decision analysis to support the search for less conflicting policy options in a multi-actor context: case study. Journal of MultiCriteria Decision Analysis, 10(2), 111-125. 
Bana e Costa, C. A., da Silva, F. N., \& Vansnick, J. C. (2001). Conflict dissolution in the public sector: A case-study. European Journal of Operational Research, 130(2), 388-401.

Bana e Costa, C. A., \& Oliveira, R. C. (2002). Assigning priorities for maintenance, repair and refurbishment in managing a municipal housing stock. European Journal of Operational Research, 138(2), 380-391.

Bana e Costa, C. A., da Costa-Lobo, M. L., Ramos, I. A., \& Vansnick, J. C. (2002a). Multicriteria approach for strategic town planning (pp. 429-456). Springer US.

Bana e Costa, C. A., Barroso, L., \& Soares, J. O. (2002b). Qualitative modelling of credit scoring: a case study in banking. Journal of European Research Studies, 1, 2.

Bana e Costa, C. A., Corrêa, É. C., De Corte, J. M., \& Vansnick, J. C. (2002c). Facilitating bid evaluation in public call for tenders: a socio-technical approach. Omega, 30(3), 227-242.

Bana e Costa, C. A., \& Chagas, M. P. (2004). A career choice problem: An example of how to use MACBETH to build a quantitative value model based on qualitative value judgments. European Journal of Operational Research,153(2), 323-331.

Cebeci, U. (2009). Fuzzy AHP-based decision support system for selecting ERP systems in textile industry by using balanced scorecard. Expert Systems with Applications, 36(5), 8900-8909.

Chatterjee, P. \& Chakraborty, S. (2012). Material selection using preferential ranking methods, Materials and Design, 35, 384-393.

Chatterjee, P., \& Chakraborty, S. (2014). Flexible manufacturing system selection using preference ranking methods: a comparative study.International Journal of Industrial Engineering Computations, 5(2), 315-338.

Clivillé, V., Berrah, L., \& Mauris, G. (2007). Quantitative expression and aggregation of performance measurements based on the MACBETH multi-criteria method. International Journal of Production Economics, 105(1), 171-189.

Das, M. C., Sarkar, B., \& Ray, S. (2012). A framework to measure relative performance of Indian technical institutions using integrated fuzzy AHP and COPRAS methodology. Socio-Economic Planning Sciences, 46(3), 230-241.

Dhouib, D. (2014). An extension of MACBETH method for a fuzzy environment to analyze alternatives in reverse logistics for automobile tire wastes. Omega, 42(1), 25-32.

Ertuğrul, İ., \& Karakaşoğlu, N. (2008). Comparison of fuzzy AHP and fuzzy TOPSIS methods for facility location selection. The International Journal of Advanced Manufacturing Technology, 39(78), 783-795.

Fakhfakh, N., Verjus, H., Pourraz, F., \& Moreaux, P. (2011). Measuring the satisfaction degree of quality attributes requirements for services orchestrations. In Fourth International Conference on Communication Theory, Reliability, and Quality of Service (CTRQ 2011) (pp. 89-94).

Ilangkumaran, M., \& Kumanan, S. (2009). Selection of maintenance policy for textile industry using hybrid multi-criteria decision making approach.Journal of Manufacturing Technology Management, 20(7), 1009-1022.

Kaklauskas, A., Zavadskas, E. K., \& Raslanas, S. (2005). Multivariant design and multiple criteria analysis of building refurbishments. Energy and Buildings, 37(4), 361-372.

Kaklauskas, A., Zavadskas, E. K., Raslanas, S., Ginevicius, R., Komka, A., \& Malinauskas, P. (2006). Selection of low-e windows in retrofit of public buildings by applying multiple criteria method COPRAS: A Lithuanian case.Energy and Buildings, 38(5), 454-462.

Kaklauskas, A., Zavadskas, E. K., \& Trinkunas, V. (2007a). A multiple criteria decision support online system for construction. Engineering Applications of Artificial Intelligence, 20(2), 163-175.

Kaklauskas, A., Zavadskas, E. K., Banaitis, A., \& Šatkauskas, G. (2007b). Defining the utility and market value of a real estate: a multiple criteria approach. International Journal of Strategic Property Management, 11(2), 107-120.

Kaklauskas, A., Zavadskas, E. K., Naimavicienė, J., Krutinis, M., Plakys, V., \& Venskus, D. (2010). Model for a complex analysis of intelligent built environment. Automation in Construction, 19(3), 326-340. 
Kanapeckiene, L., Kaklauskas, A., Zavadskas, E. K., \& Seniut, M. (2010). Integrated knowledge management model and system for construction projects. Engineering Applications of Artificial Intelligence, 23(7), 1200-1215.

Karande, P., \& Chakraborty, S. (2013). Using MACBETH method for supplier selection in manufacturing environment. International Journal of Industrial Engineering Computations, 4(2), 259-279.

Karande P. \& Chakraborty, S. (2014). A facility layout selection model using MACBETH method, Proceedings of the 2014 International Conference on Industrial Engineering and Operations Management, January $7-9$, Bali, Indonesia.

Madhuri, B. Ch., Anand Chandulal, J., Padmaja, M.(2010a). Selection of best web site by applying COPRAS-G method. International Journal of Computer Science and Information Technologies, 1(2), 138-146.

Maity, S. R., Chatterjee, P., \& Chakraborty, S. (2012). Cutting tool material selection using grey complex proportional assessment method. Materials \& Design, 36, 372-378.

Mokhtari, M., Javanshir, H., Dolatabadi, M.K., Tashakori, L., \& Madanchi, F. (2013). Supplier selection in textile industry using fuzzy MADM, Research Journal of Applied Sciences, Engineering and Technology, 6(3), 400-411.

Montignac, F., Noirot, I., \& Chaudourne, S. (2009). Multi-criteria evaluation of on-board hydrogen storage technologies using the MACBETH approach.International Journal of Hydrogen Energy, 34(10), 4561-4568.

Mulliner, E., Smallbone, K., \& Maliene, V. (2013). An assessment of sustainable housing affordability using a multiple criteria decision making method. Omega, 41(2), 270-279.

Popovic, G., Stanujkic, D., \& Stojanovic, S. (2012). Investment project selection by applying copras method and imprecise data. Serbian Journal of Management, 7(2), 257-269.

Rodrigues, T. C. (2014). The MACBETH approach to health value measurement: Building a population Health index in group processes.Procedia Technology, 16, 1361-1366.

Roubens, M., Rusinowska, A., \& De Swart, H. (2006). Using MACBETH to determine utilities of governments to parties in coalition formation. European Journal of Operational Research, 172(2), 588-603.

Salomon, V. A., \& Montevechi, J. A. B. (2001, August). A compilation of comparisons on the analytic hierarchy process and others multiple criteria decision making methods: some cases developed in Brazil. In 6th International Symposium on the Analytic Hierarchy Process, Bern.

Vilutienė, T., \& Zavadskas, E. K. (2003). The application of multi-criteria analysis to decision support for the facility management of a residential district. Journal of Civil Engineering and Management, 9(4), 241-252.

Viteikiene, M., \& Zavadskas, E. K. (2007). Evaluating the sustainability of Vilnius city residential areas. Journal of Civil Engineering and Management,13(2), 149-155.

Yayla, A. Y., Yildiz, A., \& Yildiz, K. (2013). A generalized Choquet integral algorithm for subcontractor selection in textile industry-A case study for Turkey. Fibres \& Textiles in Eastern Europe, 6(102), 16-21.

Zagorskas, J., Burinskienè, M., Zavadskas, E., \& Turskis, Z. (2007). Urbanistic assessment of city compactness on the basis of GIS applying the COPRAS method. Ekologija, 53(2), 55-63.

Kaklauskas, A., Zavadskas, E. K., \& Raslanas, S. (2005). Multivariant design and multiple criteria analysis of building refurbishments. Energy and Buildings, 37(4), 361-372.

Zavadskas, E. K., \& Vilutienè, T. (2004). Multi-criteria analysis of multi-family apartment blocks maintenance service packages. Journal of Civil Engineering and Management, 10 (Suppl 2), 143 152.

Zavadskas, E. K., Kaklauskas, A., Banaitis, A., \& Kvederyte, N. (2004). Housing credit access model: The case for Lithuania. European Journal of Operational Research, 155(2), 335-352.

Zavadskas, E.K., Kaklauskas, A., Peldschus, F. \& Turskis, Z. (2007). Multi-attribute assessment of road design solution by using the COPRAS method. The Baltic Journal of Road and Bridge Engineering, 2(4), 195-203. 
Zavadskas, E.K., Kaklauskas, A., Turskis, Z. \& Tamošaitiene, J. (2008a). Selection of the effective dwelling house walls by applying attributes values determined at intervals. Journal of Civil Engineering and Management, 14(2), 85-93.

Zavadskas, E.K., Turskis, Z., Tamosaitiene, J., \& Marina, V. (2008b). Selection of construction project managers by applying Copras-G method, The 8th International Conference "Reliability and Statistics in Transportation and Communication - 2008”, RelStat'08, 15-18 October 2008, Riga, Latvia.

Zavadskas, E.K., Kaklauskas, A., Turskis, Z. \& Tamosaitiene, J. (2008c). Contractor selection multiattribute model applying Copras method with grey interval numbers, 20th EURO Mini Conference "Continuous Optimization and Knowledge-Based Technologies" (EurOPT-2008), May 20-23, 2008, Neringa, Lithuania.

Zavadskas, E.K., Kaklauskas, A. \& Vilutiene, T. (2009). Multicriteria evaluation of apartment blocks maintenance contractors: Lithuanian case study, International Journal of Strategic Property Management, 13(4), 319-338. 